\title{
Using integrated land- and boat-based surveys to inform conservation of the Critically Endangered Balearic shearwater
}

\author{
Alice R. Jones ${ }^{1,6, *}$, Russell B. Wynn ${ }^{1}$, Pierre Yésou ${ }^{2}$, Laurent Thébault ${ }^{3}$, \\ Philip Collins ${ }^{1,4}{ }^{\text {, Lavinia Suberg }}{ }^{1}$, Kate M. Lewis ${ }^{5}$, Tom M. Brereton ${ }^{5}$ \\ ${ }^{1}$ National Oceanography Centre - Southampton, European Way, Southampton SO14 3ZH, UK \\ ${ }^{2}$ Office National de la Chasse et de la Faune Sauvage (ONCFS), 39 Boulevard Albert Einstein, 44300 Nantes, France \\ ${ }^{3}$ Groupe d'Etudes Ornithologique des Côtes d'Armor (GEOCA), Couign ar fao, Kerlaudy, 29420 Plouenan, France \\ ${ }^{4}$ School of Life Sciences, University of Roehampton, Holybourne Avenue, London SW15 4JD, UK \\ ${ }^{5}$ MARINElife, 12 St Andrews Road, Bridport, Dorset DT6 3BG, UK
}

${ }^{6}$ Present address: The Environment Institute \& School of Earth and Environmental Sciences, University of Adelaide, South Australia 5005, Australia

\begin{abstract}
We investigated spatio-temporal distribution patterns of the Critically Endangered Balearic shearwater Puffinus mauretanicus in the northern part of its migratory range, using a combination of effort-corrected land- and boat-based survey data (2007-2010). The species was recorded regularly along the western English Channel (Western Channel) coasts of northwest France and the southwest UK, with peak counts occurring during the summer and autumn months. Foraging aggregations comprising hundreds to thousands of birds $(\sim 1$ to $20 \%$ of the global population) were recorded in the large shallow embayments of northern Brittany in all survey years. Elsewhere, most birds were recorded on passage, with maximum birds-per-hour (BPH) of 169 off northwest France and 36 off the southwest UK. Few birds were recorded offshore, beyond sight of land. A distance-from-shore analysis revealed that the species passed closer to shore than other pelagic seabirds such as sooty shearwater Puffinus griseus. A constant-effort seasonal survey from the southwest tip of the UK mainland recorded the species on $93 \%$ of survey days, with BPH rates peaking in the morning between 08:00 and 11:00 h. These results have important monitoring and conservation implications for this Critically Endangered species. In particular, the records of large aggregations in spatially restricted areas of the Western Channel during the inter-breeding period suggests the species could be vulnerable to impacts such as oil spills, or disturbance from offshore construction projects. We also provide evidence that some birds remain in the survey area during the breeding season, suggesting it may be an important site for non-breeding birds.
\end{abstract}

KEY WORDS: Balearic shearwater - Puffinus mauretanicus - Spatio-temporal distribution · Visual monitoring $\cdot$ Critically Endangered $\cdot$ Western Channel $\cdot$ Conservation

\section{INTRODUCTION}

Effective protection of endangered seabirds is facilitated by a comprehensive understanding of the spatio-temporal patterns in their distribution throughout their full range (Phillips et al. 2006) and for all age

${ }^{*}$ Corresponding author: alice.jones01@adelaide.edu.au cohorts (Croxall et al. 2005). Improvements in tracking technologies have dramatically increased our ability to collect data on the movement and behaviour of individual birds, with high resolution and for prolonged time periods (e.g. Guilford et al. 2008, 2009, Lewison et al. 2012). However, as a result of financial restricted. Authors and original publication must be credited. 
and logistical constraints, tracking studies are (1) typically focused on breeding birds, (2) colony specific and (3) only include a small proportion of a species' population. Therefore, it is important to recognise the continued value of visual monitoring and the contribution that both opportunistic sighting records and systematic effort-based surveys can make to the understanding of seabird distributions, particularly during the non-breeding season while the birds are at sea. This is especially pertinent for rare or charismatic species with predominantly coastal distributions, which generate interest among seabird observers and as a result are often well recorded throughout their range (Booth et al. 2011). In this study we use effort-corrected sightings data from both opportunistic and dedicated visual monitoring surveys to present an overview of the spatio-temporal distribution and behaviour of the Critically Endangered Balearic shearwater Puffinus mauretanicus within the western English Channel (hereafter Western Channel) off the southwest UK and northwest France.

The Balearic shearwater is listed on the IUCN Red List as 'Critically Endangered' as a result of its small breeding range and evidence of rapid population decline (Oro et al. 2004, BirdLife International 2012), with the most recent estimate of the breeding population at 3200 pairs (Arcos 2011). However, surveys of migratory passage through the Straits of Gibraltar, and wintering aggregations in the western Mediterranean, suggest a total population of up to 25000 birds (Arroyo et al. 2008, Arcos et al. 2012a). This is considerably higher than extrapolation from estimates of the breeding population would suggest, although a recent tracking study by Guilford et al. (2012) shows that birds may move in and out of the Atlantic through the Straits of Gibraltar multiple times in a single season, and therefore may be contributing to duplication in the Gibraltar flyway point counts. Alternatively, there may be undiscovered breeding colonies or a large 'floating' non-breeding population, leaving some uncertainty as to the species' demographics and census (Varty \& Tanner 2009, Arcos 2011). Little demographic research has been published since Oro et al. (2004); therefore, our understanding of the current state of the population is limited and warrants further study. Irrespective of these uncertainties, previous research shows an overall decline in the population of the species, evidenced by monitoring at a number of colonies within the species' limited breeding range on the Spanish Balearic Islands of Mallorca, Menorca, Ibiza and Formentera (Fig. S1 in the Supplement at www.int-res. com/articles/suppl/n025p001_supp.pdf) (Oro et al.
2004, Ruiz \& Marti 2004, Arcos 2011, Arcos et al. 2012a).

Recent population declines have been attributed to anthropogenic impacts that have led to low adult survival rates of $\sim 0.78$ (Oro et al. 2004). The 2 main threats to the species are thought to be at-sea mortality as a result of bycatch in commercial fishing gear, and predation of adult birds at the breeding colonies by both natural predators (Wynn et al. 2010b) and introduced species such as feral cats (Arcos 2011). Breeding colonies in the Balearic Islands have therefore been designated as Important Bird Areas by BirdLife International and as Special Protection Areas under the EC Birds Directive (Annex I). However, the main downfall in the safeguarding of the species lies in the lack of at-sea protection (Arcos et al. 2012b); therefore, identification and protection of key areas for the species away from the breeding grounds is essential.

Breeding areas on the Balearic Islands in the western Mediterranean are occupied by breeding and non-breeding birds from September to July and breeding occurs between February and May (Arcos 2011, Guilford et al. 2012). After breeding, productivity in the Mediterranean Sea drops with the onset of the summer stratification of the water column (Vous 1976, Estrada 1996). At this time, the birds migrate westwards out of the Mediterranean Sea, typically dispersing northwards into the productive coastal areas of the northeast Atlantic, although some birds move southwards along the Atlantic coast of Morocco (Le Mao \& Yésou 1993, Mayol-Serra et al. 2000, Louzao et al. 2006, Guilford et al. 2012, Louzao et al. 2012).

Recent studies show that areas along the western coast of Iberia provide key habitat for the species outside of the breeding season (Poot 2005, Guilford et al. 2012). In the past, the species was also abundant during non-breeding periods along the northern coast of the Bay of Biscay, where they foraged on rich anchovy and sardine stocks (Mayol-Serra et al. 2000, Yésou 2003). Since the mid-1990s, there has been an increase in reports of Balearic shearwaters from along northwest European coasts during the postbreeding period (Wynn \& Yésou 2007, Wynn 2009), particularly the Western Channel coasts of northwest France and the southwest UK (Wynn \& Yésou 2007, Darlaston \& Wynn 2012). This apparent northwards extension is coincident with a decline in numbers reported from the Bay of Biscay (Yésou 2003) and indicates that the inshore waters of more northerly regions are being utilised by increasing numbers of Balearic shearwaters (Wynn \& Yésou 2007, Wynn 
Fig. 1. Study area map (20072010). (†) Locations of all sites that submitted non-effort-corrected public sightings reports to the SeaWatch SW Balearic shearwater UK monitoring project in southwest England (Isles of Scilly, Cornwall, Devon, Dorset and Somerset). $(\Delta)$ Locations of SeaWatch SW effort-based strategic surveys: Gwennap Head (Cornwall, UK), and the 'sister sites' off the southwest UK. (ם) Locations of effortcorrected survey sites in NW France (data from Trektellen online database, Troost 2012). Other notable locations are labelled

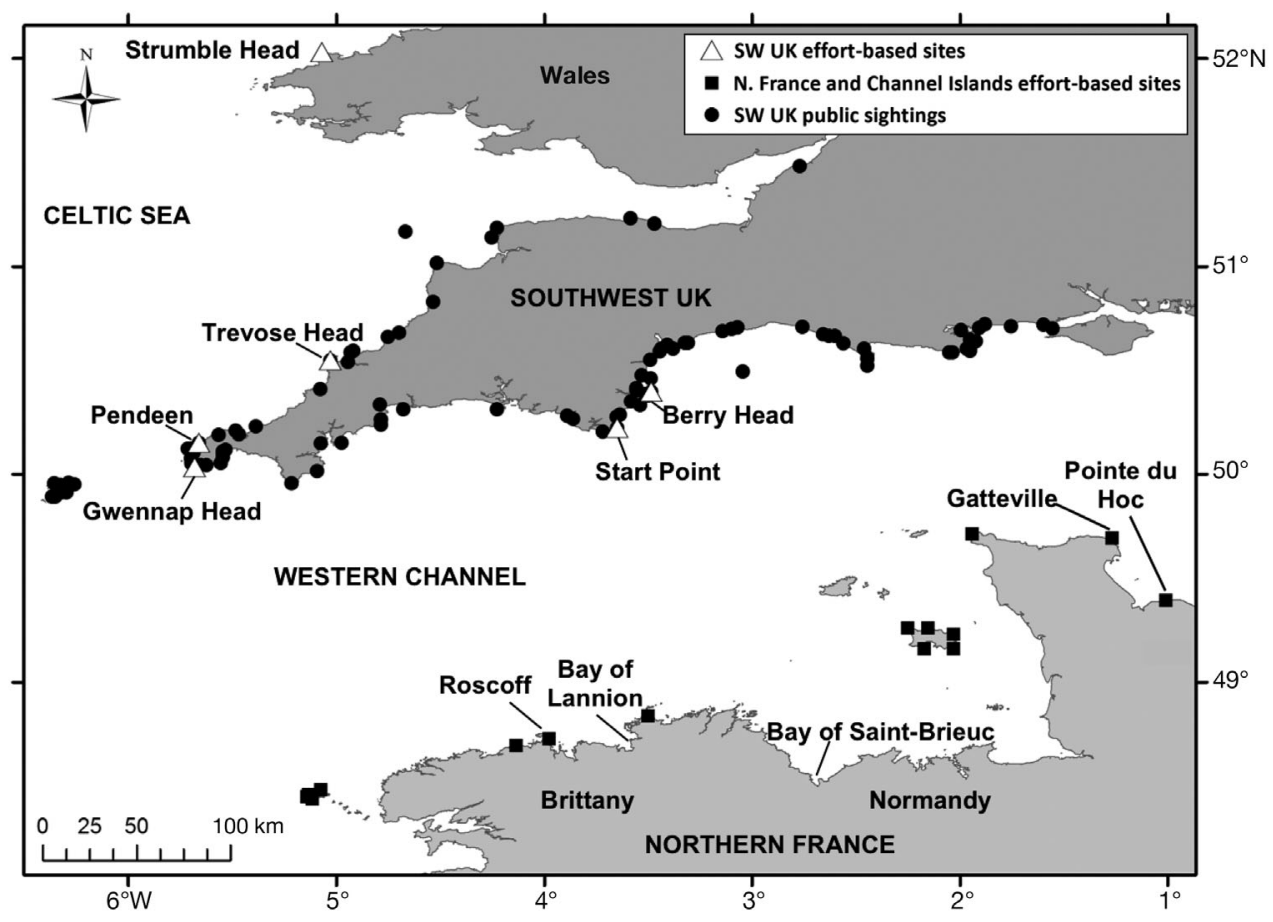

2009). Interestingly, a recent year-round tracking study of Mallorcan breeding birds provided no evidence of them migrating this far north (Guilford et al. 2012). However, tracking data are limited in terms of sample size and may not represent the full species migratory range due to colony- and individualspecific migratory strategies.

The recent changes in post-breeding distribution may be associated with bottom-up controls related to increases in North Atlantic sea surface temperature (Wynn et al. 2007, Luczak et al. 2011), and related changes in prey fish and discard availability in the Bay of Biscay (Yésou 2003, Poulard \& Blanchard 2005, ICES 2008a, Irigoien et al. 2009). It has also been suggested that the altered taxonomic status of the species in the early 1990s may have resulted in increased awareness and better recording, leading to the impression of increasing numbers further north (Votier et al. 2008a). Nevertheless, the fact remains that internationally important numbers $(>1 \%$ of the global population) of Europe's only Critically Endangered seabird have been consistently recorded off northwest France and the southwest UK and Ireland over the last 15 yr (Wynn \& Yésou 2007, Wynn 2009, Darlaston \& Wynn 2012).

In this study, we have utilised an extensive landand boat-based visual monitoring data set, collected from 2007 to 2010, to investigate the spatio-temporal distribution of the Balearic shearwater in a key area of the species' northern migratory range. The aims of the study were twofold: (1) to aid identification of seasonally important foraging/roosting sites and flyways in order to focus effective conservation efforts within the study area, and (2) to provide an update on the previously reported increase in abundance of the species within the study area.

\section{MATERIALS AND METHODS}

\section{Study area}

A map indicating the extent of the study area is shown in Fig. 1 and includes an area of the Western Channel covering approximately $77640 \mathrm{~km}^{2}$, from the Isle of Wight and Cherbourg in the east, to the Isles of Scilly and western Brittany in the west; as well as the coastlines of the southwest UK (Cornwall, Devon, Somerset, Dorset and the Isles of Scilly), northwestern France (Brittany and Normandy) and the Channel Islands. A map of the species' range is provided in Fig. S1 in the Supplement.

\section{Land-based sightings data, 2007-2010}

Collation of effort-corrected opportunistic sightings data from northwest France and the Channel Islands

Records of Balearic shearwater sightings from 2007 to 2010 were collated from the online database Trektellen (Troost 2012), which includes information on 
survey effort at each site (number of hours watched); this enabled counts to be effort-corrected and presented as birds per hour (BPH).

These data were not considered powerful enough to support statistical analyses due to their opportunistic nature. The French and Channel Islands records are therefore presented as effort-corrected peak BPH maps (2007-2010; see Figs. 2 \& 3), created in ArcGIS v.10. These show the highest values of birds counted per hour of effort from each site over the $4 \mathrm{yr}$ study period.

SeaWatch SW effort-based visual monitoring off the southwest UK in 2007-2010

Effort-based visual monitoring of Balearic shearwaters was carried out during the annual SeaWatch SW survey from Gwennap Head, Cornwall, a southfacing headland located $30 \mathrm{~m}$ above sea level at the southwest tip of the UK mainland (Wynn \& Brereton 2008, 2009, Wynn et al. 2010a). The site is recognised as an important flyway for Balearic shearwaters and other seabirds passing between the Western Channel and the Celtic Sea (Fig. 1) (Wynn \& Yésou 2007).

The SeaWatch SW survey ran for $93 \mathrm{~d}$ between 15 July and 15 October, annually, from 2007 to 2010. Observations began no more than 40 min after sunrise and finished no more than 40 min before sunset (unless in extreme weather conditions), with a break between 12:00 and 14:00 $\mathrm{h}$ to prevent observer fatigue and to avoid the period of maximal glare. Survey dates were based on the peak period for Balearic shearwater sightings off the southwest UK (Wynn \& Yésou 2007). Observers employed continuous telescope, binocular and naked eye scanning to ensure even surveillance of near and far-fields. All observers $(\mathrm{N}=29)$ were practised at seabird surveys and proven to have prior experience of Balearic shearwater identification in the field.

All records of Balearic shearwater from the Gwennap Head survey included date, time, number of birds, flight direction and estimated distance from watchpoint. Additionally, visibility $(\mathrm{km})$, glare (\% sea surface) and cloud cover ( $\%$ visible sky) were recorded hourly. Total observation effort over the 4 -yr period was almost $4000 \mathrm{~h}$ ( 1000 h per year), but the data set has been filtered to remove effort and sightings data collected in poor visibility conditions. Periods with visibility $<2 \mathrm{~km}$ and/or sightings that were estimated to be $>2 \mathrm{~km}$ offshore have been excluded as a safeguard against introducing bias due to reduced detectability and identification ability. The final data set contains 5394 sightings of Balearic shearwater collected during $3324 \mathrm{~h}$ of survey effort (see Table S1 in the Supplement at www.int-res.com/ articles/suppl/n025p001_supp.pdf).

Further effort-based data from strategic headland watch points around the coast of the southwest UK were collected by experienced observers at the SeaWatch SW 'sister sites': Berry Head/Start Point, Trevose Head, Pendeen and Strumble Head (Fig. 1). Survey effort was recorded at the sister sites; therefore, data can be effort-corrected by conversion into $\mathrm{BPH}$. The sister site data included information on the date and time of sightings, as well as total daily survey effort; however, further details (such as daily observation start/end times and survey conditions) were not regularly recorded. The amount of survey effort collected at each site varied; for example, no monitoring was carried out during 2007 and 2008 at Pendeen (Table 1). At Berry Head/Start Point and Trevose Head, data were collected throughout the year in all 4 yr of the study (Table 1).

Note that because the data were not collected in a systematic way at the sister sites, bias may have been introduced by observers only attending the sites during conditions that are favourable for nearshore seabird passage, e.g. at certain times of day or in certain weather conditions.

All sightings from targeted UK (SeaWatch SW) land-based surveys were effort-corrected by conversion into BPH. The peak BPH data were mapped, along with the French and Channel Islands data, to assess seasonal and annual variation in spatial patterns of distribution.

Diurnal patterns in BPH rates from the seasonal, constant-effort survey at Gwennap Head were investigated using a generalised least squares (GLS) model, which contains parameters to account for the heterogeneity and correlation structure of the data. The analysis tested for differences in the average rates of passage recorded by hour of the day, with the hypothesis that bird passage would not be distributed equally through the day. The model was fit in $\mathrm{R}$ software (R Development Core Team 2011) using the packages 'nlme' (Pinheiro et al. 2012) and 'rms' (Harrell 2012). Hours of the day with cumulative effort of $\mathrm{N}<100 \mathrm{~h}$ across all $4 \mathrm{yr}$ were removed prior to analysis; this only affected time periods around dawn and dusk, which were rarely included in the observation effort.

Records of Balearic shearwater from the Gwennap Head survey included an estimation of distance from shore. Distance was estimated by eye, with the aid of the Runnelstone Buoy as a marker, which was 
Table 1. Balearic shearwater Puffinus mauretanicus sightings data (2007-2010) from opportunistic effort-corrected surveys in northwestern France (collated from the Trektellen online database, Troost 2012) and targeted effort-corrected surveys in the southwest UK (from the SeaWatch SW primary observation site at Gwennap Head and the 4 sister sites in Devon, Cornwall and west Wales). BPH: birds per hour; N/A: not applicable

\begin{tabular}{|c|c|c|c|c|}
\hline & 2007 & 2008 & 2009 & 2010 \\
\hline \multicolumn{5}{|c|}{ Northwest France \& the Channel Islands } \\
\hline No. of sites with records & 12 & 14 & 16 & 16 \\
\hline Mean BPH (SD) & $7.6(6.8)$ & $26.0(28.6)$ & $30.5(42.7)$ & $16.9(16.5)$ \\
\hline Peak BPH (month) & 22 (Nov/Dec) & 105 (Aug) & 169 (Sep) & 57 (Sep) \\
\hline Location of peak BPH record & Roscoff & Gatteville & Roscoff & Pointe du Hoc \\
\hline \multicolumn{5}{|l|}{ Gwennap Head, UK (Jul-Oct annually) } \\
\hline Hours of effort & 829 & 824 & 821 & 850 \\
\hline Probability of sighting & 0.56 & 0.48 & 0.49 & 0.67 \\
\hline Mean BPH (SD) & $1.4(2.1)$ & $1.02(1.7)$ & $1.35(2.6)$ & $2.72(4.2)$ \\
\hline Peak BPH (month) & 21 (Aug) & 19 (Oct) & 28 (Oct) & 36 (Sep) \\
\hline Sighting positive days ( $\%$ of effort) & $87(92)$ & $86(92)$ & $85(91)$ & $92(99)$ \\
\hline \multicolumn{5}{|l|}{ Strumble Head, UK (Jul-Oct annually) } \\
\hline Hours of effort & 354.5 & 526.5 & 477.9 & 339 \\
\hline Mean BPH (SD) & $0.66(0.9)$ & $0.30(0.4)$ & $0.24(0.4)$ & $0.46(0.71)$ \\
\hline Peak BPH (month) & 3.63 (Sep) & 1.81 (Oct) & 1.91 (Sep) & 2.67 (Sep) \\
\hline \multicolumn{5}{|l|}{ Pendeen, UK (Jul-Nov annually) } \\
\hline Hours of effort & N/A & N/A & 163.7 & 123.5 \\
\hline Mean BPH (SD) & N/A & N/A & $1.22(2.3)$ & $1.79(2.6)$ \\
\hline Peak BPH (month) & N/A & N/A & 15.36 (Sep) & 11.67 (Nov) \\
\hline \multicolumn{5}{|l|}{ Trevose Head, UK ${ }^{\mathrm{a}}$ (Jan-Dec annually) } \\
\hline Hours of effort & 332 & 325 & 118 & 359 \\
\hline Mean BPH (SD) & $0.84(2.3)$ & $0.80(2.2)$ & $1.1(1.3)$ & $1.4(2.5)$ \\
\hline Peak BPH (month) & 18 (Aug) & 21 (July) & 4.7 (Sep) & 21.5 (Oct) \\
\hline \multicolumn{5}{|c|}{ Berry Head/Start Point, UK (Jan-Dec annually) } \\
\hline Hours of effort & 118.7 & 312.4 & 295.7 & 174.9 \\
\hline Mean BPH (SD) & $0.91(0.9)$ & $1.85(2.0)$ & $1.39(2.1)$ & $1.89(2.5)$ \\
\hline Peak BPH (month) & 2.4 (July) & 10.9 (Aug) & 11.8 (Sep) & 9.3 (Sep) \\
\hline
\end{tabular}

$\sim 1.6 \mathrm{~km}$ south of the watchpoint. There was undoubtedly some error in the distance estimation, together with variability between observers; therefore, distance-from-shore data were grouped using $500 \mathrm{~m}$ intervals to allow for error. The empirical distribution of flight distance from shore for Balearic shearwater was compared with that of the Sooty shearwater Puffinus griseus, a long-distance pelagic migratory procellariiform, using a 2-sample KolmogorovSmirnov test ('ks.test') in the base R 'stats' package (R Development Core Team 2011).

Collation of non-effort-corrected sightings data from the southwest UK

The SeaWatch SW project established a national monitoring programme for the Balearic shearwater from 2007 to 2010; this programme involved collation of a sightings database of all non-effort-based public sightings from the UK and Ireland. From January 2007, regular appeals were made in the ornithological media for seabird observers to submit sightings of Balearic shearwaters for addition to the UK and Irish national database, held by SeaWatch SW. Sightings were submitted (1) by email directly to the SeaWatch SW co-ordinator, (2) through the SeaWatch SW website (www.seawatch-sw.org) or (3) via BirdGuides for inclusion in their Bird News Extra database (BirdGuides 2013a). Additionally, efforts were made to seek out sightings from other sources such as Trektellen (Troost 2012). Anomalous records were verified with the relevant county recorder or an experienced local observer; those that could not be verified were removed from the data set. Records from each site were assigned geographical coordinates using the sites database on the Birdguides website (BirdGuides 2013b). Only records with date, location, number of birds and source were included in the final data set, on which quality control was 
undertaken, including the removal of suspected duplicates.

It should be noted that these data are not effortbased and are therefore subject to significant limitations, including: varying amounts of effort dependent on the site, observer, time of year and/or weather conditions; varying observer ability and optical equipment. Additionally, the reporting of sightings will have been affected by the level of awareness of individual observers about the SeaWatch SW Balearic shearwater monitoring programme. These constraints have been taken into account when presenting the data. Only the data collected from the southwest UK (Cornwall, Devon, Somerset, Dorset and the Isles of Scilly) have been used in this study (Fig. 1). These data made up over $70 \%$ of the public sightings records received by the project, highlighting the importance of this region to the species, and the high level of reporting. No comparative spatial or temporal analyses have been carried out using these data. The locations of sightings have simply been used to show records of presence throughout the period of study (2007-2010; Fig. 1). In addition, these data were used to indicate the length of the sightings season for each year. This metric has been defined as the period between the first and last reported sighting of the species within the southwest UK, derived from a subset of the data containing $90 \%$ of the sightings records from each year, centred around the median sighting date (from Witt et al. 2012).

\section{Boat-based visual monitoring surveys in the Western Channel, 2007-2010}

MARINElife (www.marine-life.org.uk/) undertook a broad range of effort-related boat surveys within the Western Channel between 2007 and 2010. Surveys included: (1) monthly surveys along 3 ferry routes, with occasional surveys on another 5 routes; (2) volunteer surveys on dive, angling, eco-tourism and fishing boats; (3) a systematic survey (stratified random design) of Lyme Bay (located off the Devon and Dorset coasts; see Fig. 4B) in early winter 2009; (4) a systematic survey (stratified random design) of the entire Western Channel in summer 2009; and (5) targeted surveys in 2010 within the $10 \mathrm{~km}$ grid squares not previously surveyed by any of the above methods.

For all MARINElife surveys, data on survey effort were collected at 15-30 min intervals (or whenever the course of the ship changed) and included direction of travel, speed and position of the ship, and sea and weather conditions. On all systematic surveys, ship speed and route location were organised by MARINElife; consequently, it was possible to sample seabirds by best practice European Seabirds at Sea (ESAS) methods (for details see Text $\mathrm{S} 1$ in the Supplement at www.int-res.com/articles/suppl/n025 p001_supp.pdf and the Joint Nature Conservation Committee's website, www.jncc.gov.uk/page-4568; Tasker et al. 1984, Webb \& Durinck 1992). In total, $551 \mathrm{~km}^{2}$ were surveyed using ESAS methods on $28 \mathrm{~d}$ (14 survey days in 2009 and 14 in 2010).

On all non-targeted (opportunistic) effort-corrected boat surveys (i.e. ferries and small boats), survey methods were adapted to account for vessel type, ship speed and other limitations. The time, location and duration of stopping points (for dive or angling efforts) were also noted as appropriate (see Table S2 in the Supplement for details on methods).

Effort and Balearic shearwater sightings data from all boat surveys (2007-2010) were combined into a single database. Each record contained information on the position of the ship and environmental conditions at the start of a survey leg, position at the end of a survey leg, the survey route, positions of Balearic shearwater sightings and environmental records, the time, day, month and year. A blank record was used to mark any breaks in survey effort. The data were subject to 2 validation stages: (1) a trawl using Memory Map O2004 software to rectify any obvious transcription errors relating to latitude and longitude positions, and (2) using the CREEM/JNCC Joint Cetacean Protocol validation tool (www.ruwpa.stand.ac.uk/dpwebi/jcp/).

The data were plotted in a GIS created in ArcMap 9.3.1, and divided into a grid containing 616 cells (10 $\times 10 \mathrm{~km}$ ) where survey effort was collected, which covers approximately $80 \%$ of the defined survey area in the Western Channel. The amount of survey effort $(\mathrm{km}$ travelled) and a single measure of Balearic shearwater abundance was derived for each grid cell using data pooled across all MARINElife effortrelated surveys. Given that different survey platforms were used, and survey methods differed slightly between these, density estimates are not directly comparable for all surveys; therefore, data were amalgamated into a simple measure of relative abundance (birds recorded $\mathrm{km}^{-1}$ ). Sightings of both flying birds and those resting on the water were pooled in this analysis. This was considered acceptable because all areas were sampled in Beaufort sea state 3 or less. In these calm or slight seas, there was little difference in the detectability of sitting and flying birds within the recording areas around the ves- 
sels; therefore, birds were unlikely to have been missed.

The temporal pattern in sightings was assessed by calculating the proportions of sightings made by month, accounting for survey effort.

It is important to note that in both the land- and boat-based surveys, as with all visual survey methods, there is the potential for re-counting individual birds both within and between sampling units (i.e. days of the survey).

\section{RESULTS}

\section{Spatial distribution}

Land-based survey data from the southwest UK, northwest France and the Channel Islands

Effort-based and non-effort-based reports of Balearic shearwater sightings from land were received from 101 different observation sites around the southwest UK coast, and 20 sites along the northwest French and Channel Island coasts during the period January 2007 to December 2010 (Fig. 1).
Table 1 summarises the effort-based sightings data from the southwest UK, northwest France and the Channel Islands. Patterns in the spatial distribution of these sightings were similar in all $4 \mathrm{yr}$, with a relatively even spread of sightings reported along the French Channel coast, from Brittany in the west to Normandy in the east (Fig. 2). The BPH rates were consistently lower on the UK side of the Channel than on the French side (Fig. 2). In the UK, the most northerly of the effort-based survey sites, Strumble Head in west Wales, had the lowest $\mathrm{BPH}$ rates throughout the study period (Table 1, Figs. 2 \& 3). Effort-based monitoring data from the southwest UK were not available from any sites east of Berry Head in Devon (Fig. 1).

Boat-based survey data from the Western Channel

In total, sailings were made from 26 English and 7 French ports, using 45 different vessels, with 240 surveys completed, sampling $68308 \mathrm{~km}$ of trackline (Fig. 4A). There were 189 sightings of Balearic shearwater collected on the effort-based boat surveys; these sightings related to a cumulative total of 1397
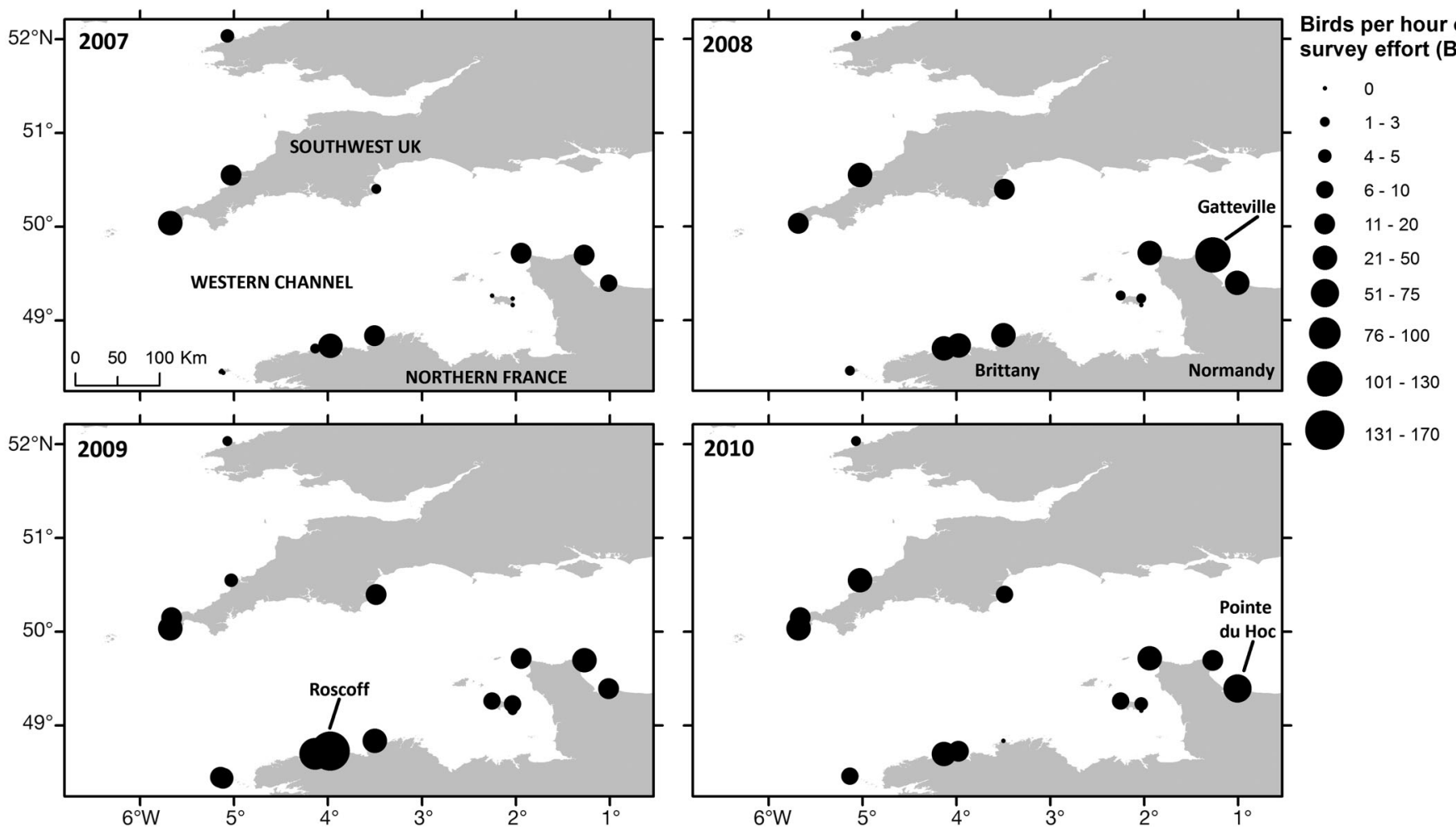

Fig. 2. Annual peak birds per hour (BPH) records of Balearic shearwaters Puffinus mauretanicus from effort-based survey sites in the southwest UK, northwest France and the Channel Islands (2007-2010). Scaled black circles indicate the highest BPH value recorded per year from each site 

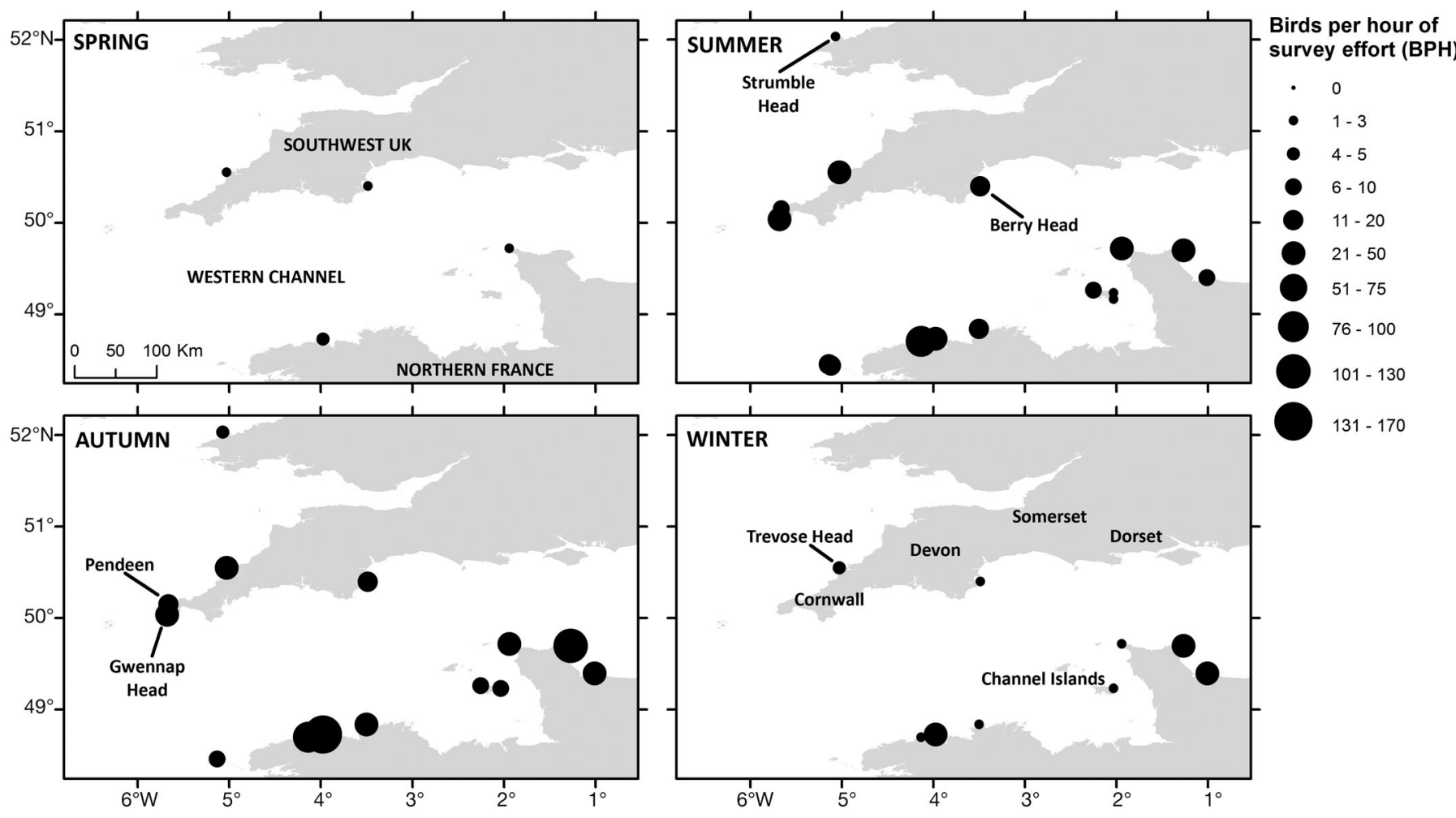

Fig. 3. Seasonal peak birds per hour (BPH) records of Balearic shearwaters Puffinus mauretanicus from effort-based survey sites in the southwest UK, northwest France and the Channel Islands (2007-2010). Scaled black circles indicate the highest BPH value recorded during each season from each site. Seasons defined as: winter, Dec-Feb; spring, Mar-May; summer, Jun-Aug; autumn, Sep-Nov. Note that effort-corrected winter and spring data were not available from Gwennap Head, Pendeen and Strumble Head in the southwest UK

Balearic shearwaters observed in the Western Channel during 2007 to 2010 . These included 33 sightings of a total of 72 birds during 114 ferry surveys, and 156 sightings of a total of 1325 birds during 196 small boat surveys. A summary of the boat-based survey data set is given in Table S2 in the Supplement.

Birds were patchily distributed in the Western Channel, being observed in only $14 \%$ of the sampled $10 \mathrm{~km}^{2}$ grid cells (Fig. 4B). Seventy-two percent of sightings were of singletons, whilst $90 \%$ were of 5 or fewer birds. When aggregations were recorded, these were either made up entirely of Balearic shearwaters, or were mixed species groups containing Manx shearwaters Puffinus puffinus. There were 5 recorded groups of Balearic shearwaters containing $>100$ individuals, all of which were sighted in the coastal waters of northern Brittany in late summer 2010. The largest rafts were of $\sim 350$ and $\sim 100$ birds in the Bay of Lannion on 27 August 2010 (1100 were counted from land prior to sailing) and 260 and 150 birds in the Bay of Saint-Brieuc on 20 September 2010. On the English side of the Western Channel, the coastal waters around Portland Bill and in Lyme Bay had the highest relative density of birds: the five $10 \mathrm{~km}^{2}$ cells that were sampled adjacent to Portland Bill accounted for $72 \%$ of all birds counted in UK waters (Fig. 4B). This area, along with the adjacent Shambles Bank to the east, was the location of all records of rafting birds. Away from Portland, only individuals or small groups (2-3) of birds were observed in 32 out of the 270 grid cells (11\%) surveyed in southwest UK waters (Fig. 4B). During the Western Channel summer survey (2009), where widespread spatial coverage was achieved over a short time scale, just 9 singletons were seen (all in flight), giving an overall mean density (uncorrected) for that period of 0.016 birds per $\mathrm{km}^{2}$. A preference for coastal waters is evident from the boat-based survey data (Fig. 4B).

\section{Temporal distribution}

Annual and seasonal patterns in sightings

After correction for effort, the annually averaged $\mathrm{BPH}$ values from the French and Channel Islands land-based surveys were lowest in 2007 and highest in 2009. The annually averaged BPH rates from the 

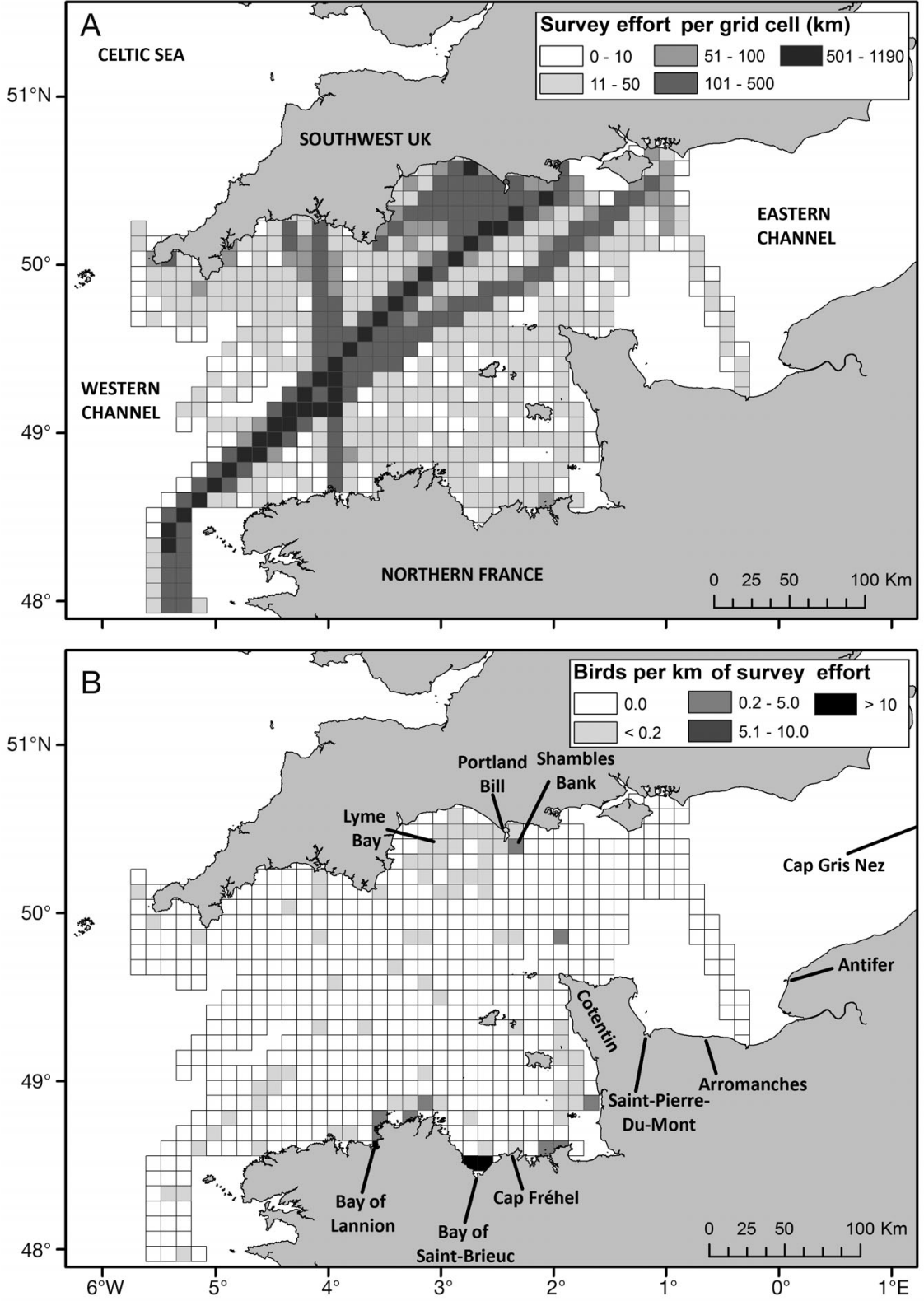

Fig. 4. MARINElife boat-based visual survey data from the Western Channel (2007-2010), gridded at $10 \times 10 \mathrm{~km}$ resolution. All cells were surveyed; unfilled cells show absence of sightings. (A) Survey effort ( $\mathrm{km}$ of trackline). (B) Relative density of Balearic shearwaters (number counted per $\mathrm{km}$ of survey effort) per day, but there was a large amount of variability associated with this average $($ mean $=14.62, \mathrm{SD}=17.13)$. The percentage of days with cumulative counts greater than the 2007-2010 mean day count of 14.62 birds ranged from $17 \%$ in 2008 to $54 \%$ in 2010 (Fig. 5). Day counts of more than 50 were made occasionally throughout the 4 -yr survey period $(2007=2$; $2008=1 ; 2009=3 ; 2010=12$ ), but these rarely occurred on consecutive days (Fig. 5). Overall, the southwest UK effort-corrected data sets had seasonally averaged passage rates of 1.02-3.94 $\mathrm{BPH}$ for the summer/autumn (JulyOctober) peak passage period. Passage rates at the northernmost effort-based survey site, Strumble Head in west Wales (UK), were markedly lower for the same season (0.26-0.7 BPH).

The seasonal patterns in $\mathrm{BPH}$ from northwestern France, the Channel Islands and the southwest UK were comparable (Fig. 3), with the highest numbers of birds reported during the autumn (peak French BPH = 169 in September 2009, peak UK BPH = 36 in September 2010) and summer (peak French BPH = 88 in August 2009, peak $\mathrm{UK} \mathrm{BPH}=35$ in August 2010). There tended to be reduced numbers of birds sighted in winter, and the fewest sightings were recorded during spring (the breeding season) (Fig. 3). This pattern is supported by the boatbased survey data, which showed that the highest percentage of offshore Balearic shearwater sightings during the survey period was recorded between July and September (Fig. 6). It should be noted that there was reduced survey effort during the spring effort-based southwest UK sites were variable through the 4 -yr study period; however, 4 of the 5 sites recorded the highest rates in 2010 (Table 1).

Balearic shearwaters were recorded on $93.5 \%$ of days in the constant-effort summer/autumn seasonal survey from Gwennap Head (15 July-15 October 2007-2010), with an inter-annual range of $91 \%$ (2007) to $99 \%$ (2010) of survey days being positive for sightings (Table 1). Cumulative daily counts from this constant-effort site were generally less than 15 birds and winter months in both the boat- and the landbased surveys (Table 1, Fig. 6).

Data from the 2 UK effort-based sites where survey effort was collected throughout the full year (Berry Head/Start Point and Trevose Head) show that the species was recorded consistently (albeit in lower numbers) throughout the winter and spring (Fig. 3). The same pattern is seen in the data from the French side of the Channel (Fig. 3). In addition, the 2007 effort-corrected BPH peak count from Roscoff (Brit- 


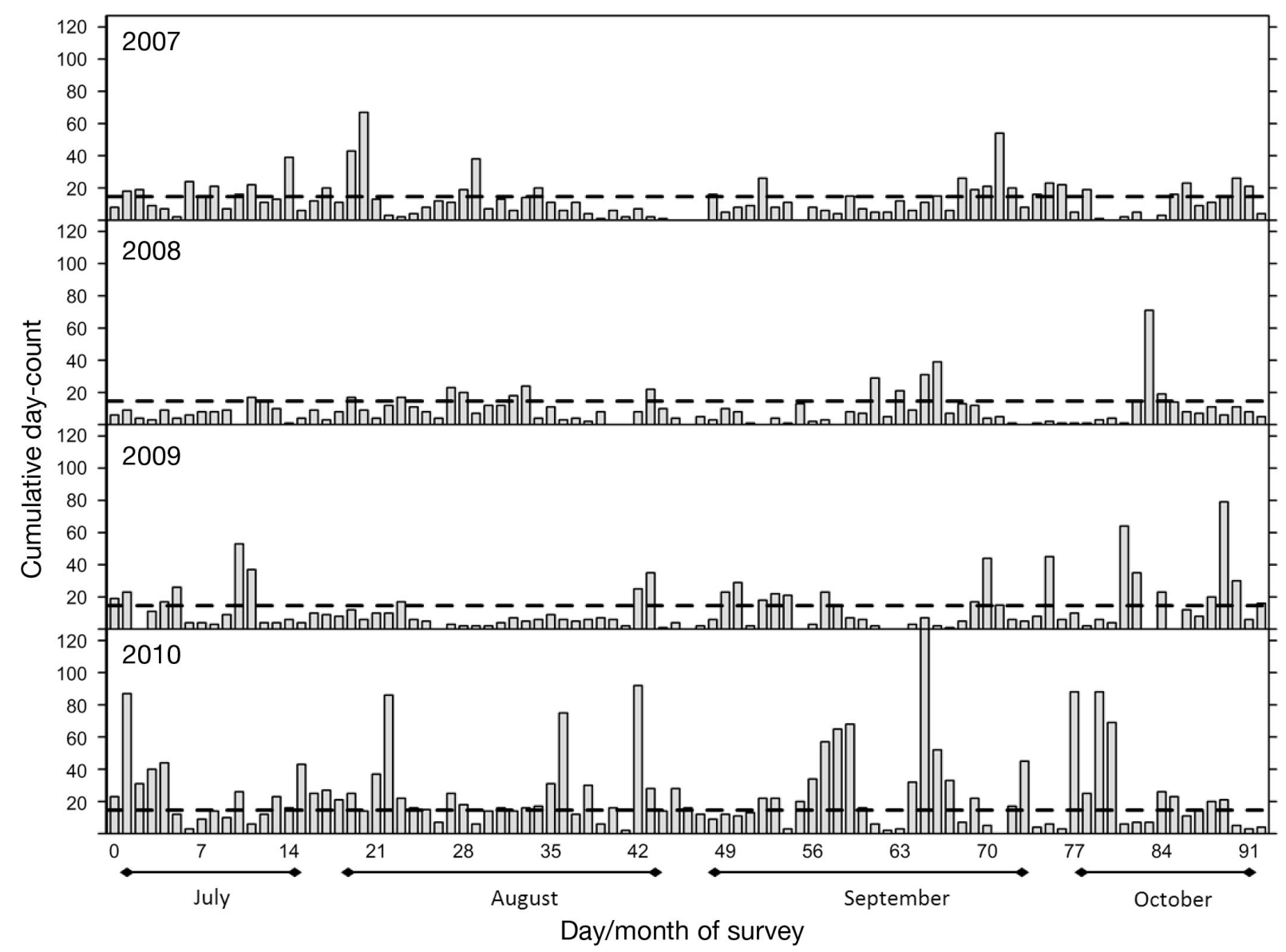

Fig. 5. Cumulative day-counts of Balearic shearwaters Puffinus mauretanicus passing the SeaWatch SW Gwennap Head constant-effort survey watchpoint between 15 July and 15 October $2007-2010$ ( $\mathrm{N}=5394$ sightings). Dashed lines show multi-year mean day count (14.6 birds per day)

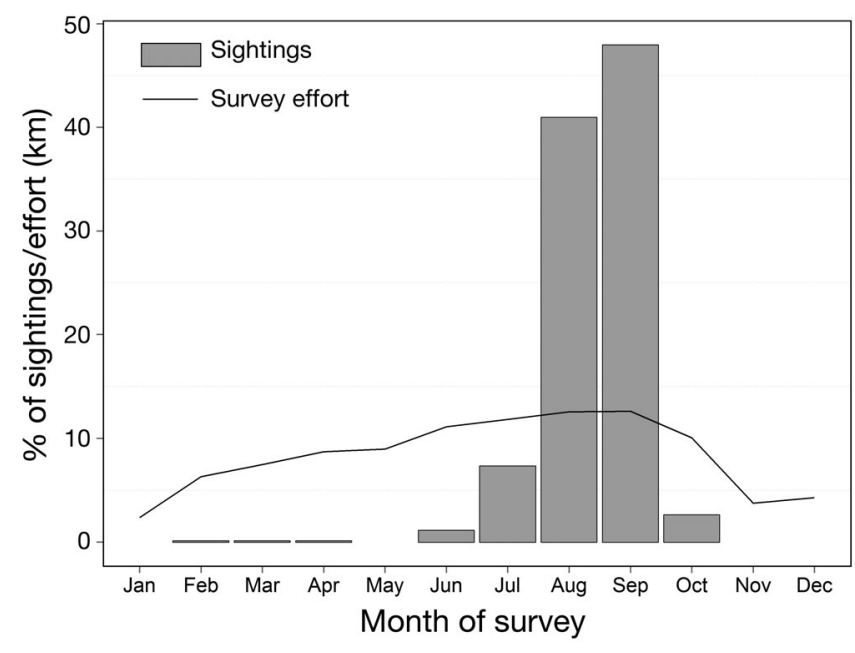

Fig. 6. Offshore Balearic shearwater Puffinus mauretanicus sightings by month (\% of total) from targeted MARINElife boat surveys ( $\mathrm{N}=189$ sightings) in the Western Channel, 2007-2010. Note that sightings rates per month have not been corrected for effort, but MARINElife survey effort $(\mathrm{km})$ per month is plotted tany, France) was made in November and December (maximum $\mathrm{BPH}=22$ in both months), and the peak 2010 BPH rate at Pendeen (Cornwall, UK) was made in November (Table 1).

Presence of the species was also recorded at many non-effort-based sites in the UK throughout winter and spring. The extent and duration of the annual Balearic shearwater sightings seasons in the southwest UK are shown in Fig. 7. The data, derived from non-effort-corrected public sightings data from 2007 to 2010 ( $\mathrm{N}=2432$ sightings), show that the presence of the species was recorded during a sightings season ranging in length from 288 to 320 d over the 4 -yr survey period. Sightings of the species in the southwest UK were recorded throughout the year from 11 January (Day 11) to 12 December (Day 346), with the median dates falling between 24 July (Day 205) and 3 September (Day 246) in all years. The 75th percentile of the southwest UK sightings season extended beyond 7 September (Day 250) in all years, and up to 15 October in 2010 (Day 289; Fig. 7). 


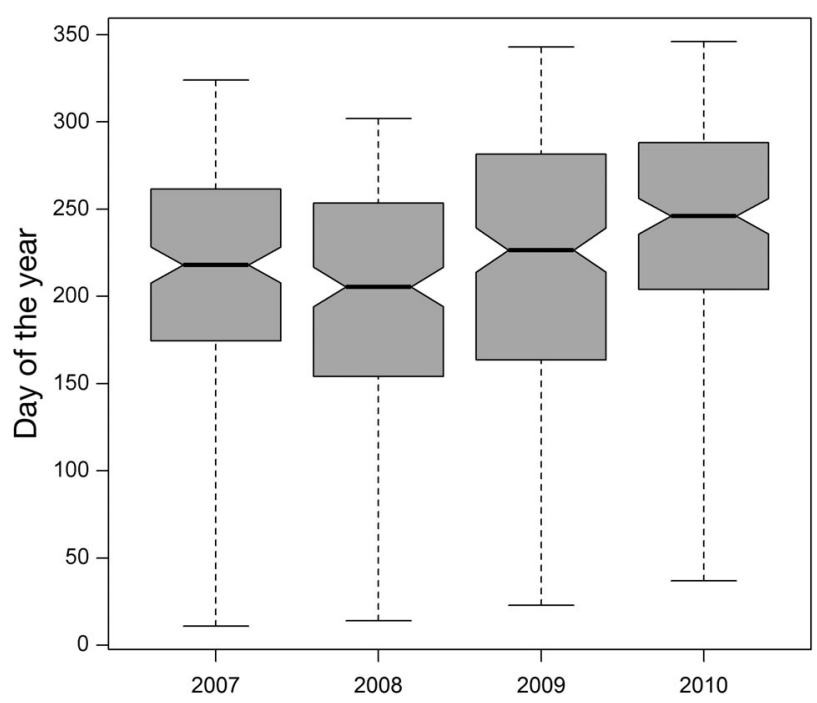

Fig. 7. Statistical distribution of presence days (days when a Balearic shearwater Puffinus mauretanicus sighting was recorded) by year, from non-effort corrected public sightings data from the southwest UK region (see Fig. 1 for location of sites). The bold horizontal line is the median day of the sightings season, and the upper and lower box limits are the 75th and 25th percentiles of the season in each year. The dashed lines extend to the extremes of the data (which is a subset of the full sightings data set, representing $90 \%$ of each year's sightings, centred on the median date)

Fine-scale temporal distribution of sightings in the Gwennap Head constant-effort survey

A total of $3324 \mathrm{~h}$ of survey effort were collected during the constant-effort seasonal survey from Gwennap Head between 15 July and 15 October 2007-2010. A total of $55 \%$ of hours were positive for Balearic shearwater sightings, with an overall average $\mathrm{BPH}$ value of 1.62 across all survey effort. The probability of a sighting in any hour of the effortbased seasonal survey at Gwennap Head ranged between years from 0.48 to 0.67 , with the highest likelihood in 2010, when there was also a large increase in the BPH compared with previous years (Table 1).

The BPH data from Gwennap Head, averaged by hour across all 4 yr of the survey, showed a diurnal pattern in sightings of Balearic shearwaters (Fig. 8), with higher BPH during the morning session of the survey (mean $\mathrm{BPH}=1.96, \mathrm{SD}=0.44$ ) than in the afternoon session (mean $\mathrm{BPH}=1.12, \mathrm{SD}=0.26$ ). Note that no data were available for the observer break period between 12:00 and 14:00 h. A Durbin-Watson test (R package 'car', function 'durbin.watson') showed that the hourly survey data were signifi- cantly temporally auto-correlated up to a lag of $14 \mathrm{~h}$ $(\mathrm{p}=0.012$ at lag 14$)$, approximately representing a daily survey period. This temporal dependence was accounted for in the analysis by including an AR1 correlation structure, based on the survey day ID, in a GLS model of the BPH data. Marginal ANOVA tests on model results indicated that hour of the day $(F=7.677, \mathrm{p}<0.001)$ had a significant effect on the observed BPH rate. Post hoc contrasts show that the hourly averaged BPH for hours between 08:00 and 11:00 $\mathrm{h}$ (inclusive) were significantly higher than $\mathrm{BPH}$ recorded during other hours of the day (corrected $p \leq 0.01$ for all contrasts of 08:00-11:00 $h$ against other hours of the day).

\section{Insights into at-sea behaviour}

Behaviour data from boat-based surveys

Behaviour was recorded for $83 \%$ of Balearic shearwater sightings made during effort-based boat surveys. The most frequently recorded behaviour $(72 \%)$ was of birds passing directly through the recording area without stopping. Although moving birds made up the majority of sightings, the actual number of birds seen in flight was low, accounting for only a small proportion of the total birds seen. This is because a few sightings ( $24 \%$ ) of larger aggregations of birds resting on the water accounted for the majority $(64 \%)$ of the total number of birds counted.

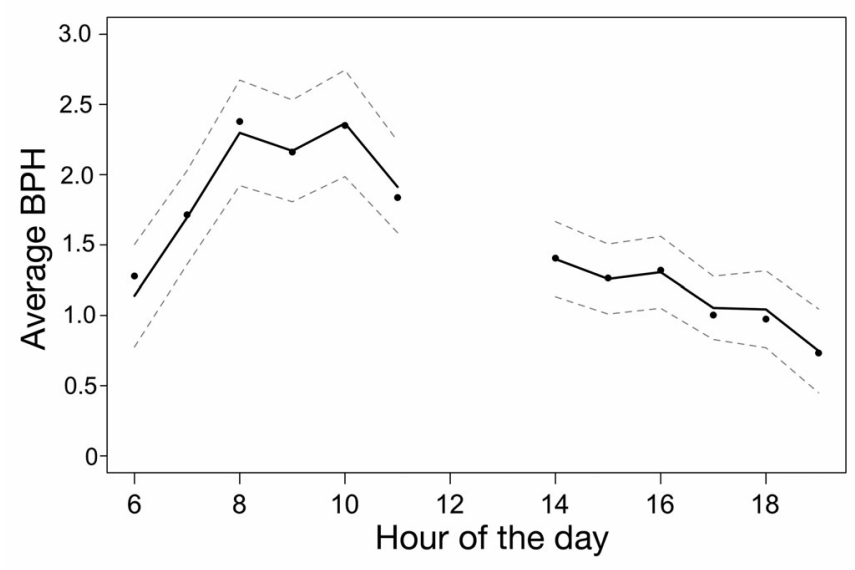

Fig. 8. Hourly averaged birds per hour (BPH) values from the SeaWatch SW effort-based survey at Gwennap Head (20072010). Note that no data were collected between 12:00 and 14:00 h. The black line is a model estimate, with $95 \%$ confidence intervals indicated by dashed grey lines; the black filled circles are the observed average BPH data ( $\mathrm{N}=3324 \mathrm{~h})$. The model is a generalised least squares model with unspecified variance structure and an AR1 autoregressive term to account for non-independence of observations 
Scavenging behaviour was observed in $15 \%$ of sightings from boats where behaviour was recorded, although these observations only involved low numbers of birds ( $4 \%$ of total birds counted). Eighteen of the 22 scavenging instances were around angling boats, likely representing greater sampling effort from/around this type of craft, with the maximum count during these encounters being 6 birds in August 2010. Self-foraging (feeding away from angling and fishing boats) was an infrequently recorded activity (observed in $8 \%$ of sightings where behaviour was recorded); however, these sightings related to more than $40 \%$ of the total number of birds counted.

Distance-from-shore analysis from Gwennap Head land-based survey

Data on the distance from shore at which Balearic shearwaters passed the survey watchpoint ( $\mathrm{N}=5394$ sightings) indicate that the majority of birds (69\%) flew within $1 \mathrm{~km}$ of the shoreline. For comparison, distance data were also collected for the sooty shearwater ( $N=1178$ sightings), a species with a more pelagic ecology (Shaffer et al. 2006), which were found to fly further offshore $(75 \%$ beyond $1 \mathrm{~km}$ from shore). The empirical distributions of the distancefrom-shore for sightings of each species were significantly different (2-sample Kolmogorov-Smirnov test, $D=0.47, \mathrm{p}<0.001)$.

\section{DISCUSSION}

The Balearic shearwater monitoring data used in this study contain a large number of both targeted and opportunistic effort-corrected observations, as well as a supporting data set of non-effort-based public sightings. The data achieve good coverage of the defined survey area and time period (Figs. 1-7). The consistency in annual and seasonal patterns between the data collected using targeted and opportunistic methods gives high confidence in the results, and supports the use of effort-corrected opportunistic data for monitoring this species.

Our study also uses some non-effort-corrected public sightings data, although the limitations of these data are significant. Non-effort-based opportunistic and public sightings data have proved useful in other recent studies investigating broad-scale distributions of migratory marine megavertebrates, such as the basking shark Cetorhinus maximus
(Witt et al. 2012) and large whale species (Richardson et al. 2012). We suggest that scarce or endangered species with a high public profile and an inshore distribution are most suitable for co-ordinated 'citizen science' marine vertebrate recording projects. However, the value of recording survey effort cannot be overstated, as it is imperative for robust comparative analyses.

\section{Spatial distribution}

The spatial distribution of sightings was consistent between years and shows that the largest numbers of birds were concentrated along the western coastlines of the survey area (Figs. 2-4). Although we could not access effort-corrected survey data from the Channel coast of southeast England, Wynn \& Yésou (2007) reported a lack of sightings in this region using noneffort-based data. However, we do show that the species was commonly recorded along the French Channel coast as far east as Pointe du Hoc during the survey period (Figs. 2 \& 3), a result that is supported by Dubois et al. (2012).

The boat survey data showed that Balearic shearwaters were generally restricted to the coastal zone within the study area, with no high-density areas identified offshore in the Channel, despite sampling approximately $80 \%$ of the study area at $10 \times 10 \mathrm{~km}$ grid resolution (Fig. 4). This is in agreement with previous surveys and habitat mapping studies from other parts of the species' range (Louzao et al. 2006, Oppel et al. 2012), and is supported by the results of the distance-from-shore analysis using the constanteffort seasonal survey data from Gwennap Head, which showed that the species tended to fly within $1 \mathrm{~km}$ of the shoreline. Péron et al. (2013) also found a preference for coastal areas in the closely related Yelkouan shearwater Puffinus yelkouan. The comparison with distance-from-shore data for sooty shearwaters recorded in the same survey, which tended to fly beyond $1 \mathrm{~km}$ from shore, indicates that this result is not simply an artefact of the survey methods (i.e. detection bias at further distances). This finding is important in terms of monitoring, as it supports the use of cost-effective, land-based surveys for this species because of its coastal affinity.

Aggregations of birds on the water were only recorded in the coastal embayments of northwest Brittany and Lyme Bay in southern England (Fig. 4) (Thébault et al. 2010). Historical evidence for large foraging and roosting aggregations of the species during the summer and autumn off northwest Brittany is 
also provided by Liéron (2000) and Wynn \& Yésou (2007), who reported peak counts of 3200 in September 1983, and >2150 in both September 1996 and July 1997. However, these embayments were not well covered by the data available from the Trektellen database for the years 2007-2010 (Fig. 1), so below we briefly summarise recently published targeted monitoring data collected in this region (Thébault et al. 2010, Février et al. 2011, Yésou et al. 2011).

The largest concentrations of birds recorded during the study period were found in 2 broad embayments in northwest Brittany: Bay of Saint-Brieuc and Bay of Lannion (for site locations, see Fig. 4). In 2007, the peak count from this region was of 1500 birds in the Bay of Saint-Brieuc on 19 October (Plestan et al. 2009). Many of these birds lingered into the winter, with at least 750 still present in January 2008 (associating with hundreds of razorbills Alca torda and kittiwakes Rissa tridactyla); this is an unprecedented winter concentration north of the Iberian peninsula (Plestan et al. 2009). Numbers in 2008 and 2009 were unexceptional, with no recorded counts exceeding 550 birds (e.g. Yésou et al. 2011). However, a record influx was noted in summer 2010, with an estimated 5780 birds present in the areas in late July, including 4630 counted in the Bay of Lannion and 1150 in the Bay of Saint-Brieuc (Thébault et al. 2010, Février et al. 2011). These counts of birds on the water are unlikely to be biased by duplicate counting of individuals, as the birds were in relatively stationary, large groups on the water.

There are fewer data available for the eastern French Channel coast. Nevertheless, records from Groupe Ornithologique Normand (GONm) suggest a marked increase in the last decade. The first record for Normandy east of Cotentin was from 1988 (there has been constant ornithological recording in Normandy since the late 1960s), and by 2000 the highest count was 7 (in October 1997). The highest count increased to 31 at Antifer in 2001, and continued to increase during the 2007-2010 survey period, with 120 birds counted on 20 September 2010 near Arromanches, and 226 birds in $3 \mathrm{~h}$ on 20 October 2010 off Saint-Pierre-de-Mont (G. Debout pers. comm.; for locations, see Fig. 4). At the eastern end of the Channel, the situation at Cap Gris-Nez/Strait of Dover showed a similar increase: until 2007, no cumulative daily record exceeded 18 birds, and then daily records increased to 84 on 7 September 2008, 100 on 5 September 2009 and 98 on 15 September 2010 (Dubois et al. 2012, Troost 2012).

This information and the results of our study indicate that there are multiple areas along the north- western French Channel coastline that have the potential to be important to large numbers of the species; however, the way the birds utilise the area is fluid and shows variability between years in terms of the location and size of aggregations, as well as their persistence. This variability is an important finding for the management and protection of Balearic shearwaters in this region. Further environmental modelling of the species' distribution in this area may aid understanding of the drivers behind this variability.

\section{Temporal distribution}

Previous studies showed that reports of Balearic shearwater increased within our study area during the mid-1990s and early 2000s in association with climatic changes and shifts in prey distribution (Yésou 2003, Wynn et al. 2007, Luczak et al. 2011). Our results generally indicate a continuation of this increase, with the highest $\mathrm{BPH}$ counts recorded at many of the effort-based sites in 2009 and 2010 (Fig. 2, Table 1), along with record numbers reported from northwest France and the southwest UK in these years (Thébault et al. 2010, Février et al. 2011, Darlaston \& Wynn 2012, Dubois et al. 2012). A cumulative count of $>5500$ birds from the northwestern French Bays of Lannion and Saint-Brieuc in late July 2010 (Thébault et al. 2010) represents $\sim 20 \%$ of the estimated world population of $\sim 25000$ individuals (Arroyo et al. 2008, Arcos et al. 2012b). Note that these birds were counted in aggregations on the water, which significantly reduces the potential bias introduced by duplicate counting, which can affect passage counts. Although large numbers have been recorded along this coastline in the past, e.g. 3200 at Cap Fréhel in September 1983 (Liéron 2000), the numbers recorded in 2010 are unprecedented in this region (Thébault et al. 2010). Likewise, a (non-effortbased) cumulative day count of 268 birds on westwards passage was recorded off Gwennap Head in September 2010, which was a record for the county of Cornwall (Darlaston \& Wynn 2012), where intensive seabird observations have been carried out for several decades. This record was exceeded in September 2011, with a cumulative day count of 283 birds on passage passing Gwennap Head ( $1 \%$ of the estimated global population), likely related to the break-up of a foraging aggregation of up to 600 birds in Lyme Bay a few days earlier (Darlaston \& Wynn 2012). These observations suggest that the summer and autumn increases in abundance in the northern part of the species' inter-breeding range (Wynn et al. 
2007, Wynn \& Yésou 2007, Wynn 2009) were sustained throughout the period 2007-2010, and that the numbers visiting the region may be increasing further. We hypothesise that a climate-change-driven northwards shift in the distribution of prey fish may be the reason behind this spatial distribution (Genner et al. 2010, Luczak et al. 2011). It is possible that individual birds showing high site fidelity may be recorded multiple times in a day from a static landbased watchpoint. However, for the following reasons we feel that this is unlikely: (1) birds were almost exclusively counted on passage (not lingering offshore), (2) the flight direction was consistent (predominantly westwards), and (3) the species' coastal affinity, which means that it is unlikely that birds doubled back further offshore and passed the watchpoint a second time flying west.

Seasonal patterns in both land- and boat-based sightings are consistent through the 4 -yr survey period, with the highest numbers recorded through summer and autumn and the lowest numbers during spring (Figs. $3 \& 6$ ). The spring withdrawal from Western Channel waters corresponds to the breeding period, when most birds are expected to be back at the colonies on the Balearic Islands in the Mediterranean (Le Mao \& Yésou 1993), arriving from September onwards. Guilford et al. (2012) tracked breeding adults from the largest known cave colony (at Sa Cella on Mallorca) with geolocators, and found that birds returned to the Mediterranean on a median date of 23 September $2010(\mathrm{~N}=26)$.

The occurrence of birds lingering into the winter and spring in the southwest UK (Figs. 3, 6 \& 7) appears to be a relatively recent phenomenon (Wynn 2009), which is also evident along the coast of northwestern France and the Channel Islands (Fig. 3). The species has been recognised to occur regularly in northern Brittany during the winter in small numbers ( 10) since the 1970s-1980s (Yésou 1991). Unprecedented numbers were recorded in the Bay of SaintBrieuc (Brittany) in winter 2007-2008 (Plestan et al. 2009). Since then, targeted surveys have found higher than usual numbers in this region during the winters of 2009-2010 and 2010-2011 (Thébault et al. 2010, 2012, Yésou et al. 2011), and a further large aggregation was recorded at the tip of Brittany in winter 2012-2013 (Pianalto et al. 2013). The presence of the species in the Western Channel through the breeding period (late autumn, winter and spring) (Table 1, Figs. $3 \&$ 7) suggests that these lingering birds are non-breeders, a group that may include juveniles, failed breeders and adult birds taking a sabbatical year from breeding. Tentative evidence for age partitioning of the population throughout the inter-breeding period can also be found in the tracking data of Guilford et al. (2012), as none of the tracked breeding birds dispersed further north than the Bay of Biscay in summer/autumn 2010, even though this period corresponded with an aggregation of $>5500$ birds ( $>20 \%$ of the global population) off northwest Brittany (Thébault et al. 2010). However, there is likely to be significant inter-annual, individual-specific and colony-specific variance in migration behaviour, so we cannot be certain that un-tracked breeding birds, or birds from other colonies, were not part of this aggregation in the Channel.

\section{Insights into at-sea behaviour}

The effort-based monitoring data from the SeaWatch SW watchpoint at Gwennap Head reveal that Balearic shearwaters pass offshore in small numbers (mean $=14.62)$ on an almost daily basis $(93.5 \%$ of days) in the summer and autumn inter-breeding period (Fig. 5). There was a $55 \%$ chance of recording birds passing the watchpoint in any given hour between July and October, with significantly higher rates in the morning than in the afternoon (Fig. 8). The drivers behind this distribution are unclear, given that Balearic shearwaters at this season are not 'central place foragers' committed to regular feeding trips to provision young at the nest, but it may be related to diurnal patterns in foraging activity and/or prey availability. Further systematic effort-based data from other headlands along the Western Channel coast would be required to assess whether this diurnal pattern in passage represents a local phenomenon, or is representative at a broader scale.

Effort-corrected data from sites off southwest England show that the overall pattern of movement is westwards, on both south- and north-facing coasts. This is interpreted to represent birds moving between the Western Channel and the Celtic/Irish Seas, and being deflected by the prominent peninsula of southwest England (Fig. 1). The numbers of birds using this 'flyway' in 2010-2011 comprised up to $2 \%$ of the world population in a single day (Darlaston \& Wynn 2012); however, away from Lyme Bay, these birds do not linger (Fig. 4) and they are rarely seen in large numbers on consecutive days (e.g. Fig. 5). It is inferred that the record numbers of birds passing the southwest UK in 2010 and 2011 (Darlaston \& Wynn 2012) originated from much larger aggregations across the Channel in northern Brit- 
tany. This interpretation is supported by behavioural observations from MARINElife boat-based surveys, with only low densities of birds seen away from the 'hotspot' areas in large embayments (Fig. 4) and 72\% of offshore sightings relating to birds in direct flight.

\section{Conservation implications}

We provide evidence that ecologically significant proportions of the Critically Endangered Balearic shearwater population are regularly visiting coastal areas of the Western Channel. This finding is relevant to the governments of the UK, France and the Channel Islands, who have an obligation to protect this listed species whilst it is in their waters.

Observations of large aggregations in bays on both the northern French and southern UK coasts, some containing up to $20 \%$ of the world population of the species, highlight the potential risk from pointsource pollution events such as oil spills (Arcos 2011). The sinking of the MV Erika off Brittany in December 1999 generated an oil spill that was considered to be one of the worst environmental disasters ever to affect France, with an estimated 100000 seabirds affected by the $>10$ million litres of oil released into the ocean (Cadiou et al. 2003, 2004). A similar disaster in summer or autumn off northern Brittany could have severe repercussions for the Balearic shearwater, either through direct mortality or by forcing the birds to move away and search for other feeding and rafting sites. Our identification of possible ageand/or colony-partitioning in the population, which was also tentatively suggested by Guilford et al. (2012), identifies a potential risk of the loss of entire age cohorts or colonies from such catastrophic events. However, age partitioning, in particular, may be beneficial at the population level because if breeders and non-breeders are spatially segregated, this can provide the opportunity for compensatory recruitment should one cohort be impacted by a catastrophic event (Votier et al. 2008b, Péron \& Grémillet 2013).

Another potential threat comes from development of renewable energy infrastructure, e.g. offshore wind turbines. For example, an offshore wind farm comprising 100 turbines and covering an area of $80 \mathrm{~km}^{2}$ is planned in the identified Balearic shearwater aggregation area of the Bay of Saint-Brieuc (Fig. 4) (WindPower 2012). Although shearwaters' moderate manoeuvrability and tendency to fly low to the water means that they are deemed to be at low risk of actually striking wind turbines (Cook et al.
2011, Furness \& Wade 2012, Furness et al. 2013), there is potential for works associated with the construction and emplacement of turbines to lead to direct disturbance and displacement of foraging and/or roosting flocks, and to indirectly impact the birds through altered prey abundance and availability.

Recent anecdotal reports from western Lyme Bay (identified here as the highest density area for the species in UK waters) indicate that Balearic shearwaters regularly follow commercial fishing boats in this area (Darlaston \& Wynn 2012), suggesting that discards may be important to this species in certain locations and at certain times of year. Furthermore, on MARINElife surveys in English waters, scavenging around fishing and angling vessels was the most frequently encountered foraging behaviour. There are some small-scale commercial long line fisheries operating within the Western Channel (Tétard et al. 1995, Cornish Fish Producers Organisation, www. cfpo.org.uk/), as well as the recent introduction of a purse seine fishery off the tip of Brittany. There is evidence for occasional accidental catch by line fishers (Thébault 2011), but there is currently no evidence to suggest that fisheries bycatch has been a significant threat to the species within the study area in recent years. This contrasts with the situation in Portuguese and Mediterranean waters, where commercial longline and seine net fishing are considered threats (Belda \& Sanchez 2001, ICES 2008b, Laneri et al. 2010, Boué et al. 2013). Further monitoring of interactions with commercial fishing boats in the northern parts of the species' range will be required to assess whether bycatch is an issue on a larger scale.

\section{Conclusions}

Our results highlight the importance of both targeted and opportunistic sightings data for providing information that can direct targeted monitoring and help inform conservation policy, such as implementation of spatial protection measures for this Critically Endangered species.

By combining fine- and broad-scale monitoring methods, we provide important information for the planning of future monitoring for Balearic shearwaters. The tendency for flight close to shore supports the use of onshore monitoring. The identification of seasonal and diurnal patterns in passage highlights the importance of spreading monitoring effort throughout the day at appropriate times of the year. In addition, the embayment aggregation sites highlighted by the boat surveys provide key information 
on rafting/foraging behaviour, which may be useful for directing spatial protection measures. However, further monitoring effort at these sites and investigation of the environmental drivers behind these aggregations is required. This will enable better understanding of the controls on inter-annual variability in the aggregations at the identified sites, as well as robust prediction of the species' distribution under changing environmental conditions.

Acknowledgements. We thank everyone who submitted reports of Balearic shearwaters to SeaWatch SW, Birdguides and Trektellen. Thanks to Gerard Troost of Trektellen; Gérard Debout and other members of GONm for data from Normandy; members of Groupe Ornithologique Breton, GEOCA, the LPO réserve nationale des Sept-îles, Bretagne Vivante; the Parc Naturel Marin d'Iroise; the Association Naturaliste d'Ouessant; and Jean Lawman for winter records from Cornwall. We also acknowledge local co-ordinators at SeaWatch SW 'sister sites': Mark Darlaston, Stan Christophers, Ray Wilkinson, Graham Rees, Adrian Rogers, John Swann and John Foster. We are extremely grateful to all volunteer observers who participated in the SeaWatch SW and MARINElife surveys, in particular assistant SeaWatch SW co-ordinator John Swann. Thanks to Miguel McMinn, Ana Rodríguez, David Johns, Jon Houghton, Clive Trueman and Rhiannon Meier, and two anonymous reviewers for comments on the manuscript. We acknowledge financial support for SeaWatch SW and MARINElife from RSPB, BTO, Natural England, Naturetrek, Total Foundation for Biodiversity, SAHFOS, RNBWS, Marine Information Ltd., The Seabird Group and Birdguides. Much of the MARINElife survey effort was part funded by the EU (INTERREG IV A) under the Channel Intergrated Approach for Marine Resource Management (CHARM) Phase 3 Project. A.J. acknowledges $\mathrm{PhD}$ and fieldwork funding from the UK Natural Environment Research Council (NERC) and SAHFOS. This paper is a contribution to the NERC Marine Environmental Mapping Programme (MAREMAP).

\section{LITERATURE CITED}

Arcos JM (2011) International species action plan for the Balearic shearwater, Puffinus mauretanicus. SEO/ Birdlife \& Birdlife International on behalf of the European Commission, Palma de Mallorca

Arcos JM, Arroyo GM, Bécares J Mateos-Rodríguez Mand others (2012a) New estimates at sea suggest a larger global population of the Balearic shearwater Puffinus mauretanicus. In: Yésou P, Baccetti N, Sultana J (eds) Ecology and conservation of Mediterranean seabirds and other species under the Barcelona Convention: update and progress. Proc 13th Medmaravis Pan-Mediterranean Symp, Alghero (Sardinia), p 84-94

Arcos JM, Becares J, Villero D, Brotons L, Rodriguez B, Ruiz A (2012b) Assessing the location and stability of foraging hotspots for pelagic seabirds: an approach to identify marine Important Bird Areas (IBAs) in Spain. Biol Conserv 156:30-42

Arroyo GM, Cuenca D, de la Cruz A, Munoz AR, Onrubia A, Ramirez J, Gonzalez M (2008) ¿Cuántas pardelas cruzan el Estrecho de Gibraltar? VI Congreso del Grupo Ibérico de Aves Marinas (GIAM), Cadiz

- Belda EJ, Sanchez A (2001) Seabird mortality on longline fisheries in the western Mediterranean: factors affecting bycatch and proposed mitigation measures. Biol Conserv 98:357-363

BirdGuides (2013a) BirdGuides News Extra. www.birdguides. com/login/login.asp? $r=1 \& d=\% 2 F b n e \% 2 F D e f a u l t \% 2 E a s p$ (accessed 13 Feb 2013)

BirdGuides (2013b) Birding sites in the UK and Ireland. www.birdguides.com/sites/default.asp (accessed 2 Oct 2013)

BirdLife International (2012) Puffinus mauretanicus. www. iucnredlist.org/details/22728432/0 (accessed 1 Oct 2013)

> Booth JE, Gaston KJ, Evans KL, Armsworth PR (2011) The value of species rarity in biodiversity recreation: a birdwatching example. Biol Conserv 144:2728-2732

Boué A, Louzao M, Arcos JM, Delord K and others (2013) Recent and current research on Balearic shearwater on colonies in Atlantic and Mediterranean areas. ACAP, La Rochelle

Cadiou B, Chenesseau D, Joslain H (2003) Marée noire de l'Erika - Contribution a l'étude de l'impact sur l'avifaune. Bilan national des échouages et de la mortalité des oiseaux (BNEMO). Rapport Bretagne VivanteSEPNB, LPO Loire-Atlantique, Observatoire des marées noires. DIREN, Bretagne

> Cadiou B, Riffaut L, McCoy KD, Cabelguen J and others (2004) Ecological impact of the 'Erika' oil spill: determination of the geographic origin of the affected common guillemots. Aquat Living Resour 17:369-377

Cook ASCP, Johnston A, Wright LJ, Burton HHK (2011) A review of flight heights and avoidance rates of birds in relation to offshore wind farms. BTO Research Report Number 618. Project SOSS-02, Crown Estate Strategic Ornithological Support Services, Thetford

> Croxall JP, Silk JRD, Phillips RA, Afanasyev V, Briggs DR (2005) Global circumnavigations: tracking year-round ranges of nonbreeding albatrosses. Science 307:249-250

Darlaston M, Wynn RB (2012) A record influx of Balearic shearwaters in Devon and Cornwall. Br Birds 105:37-38

Dubois PJ, Duquet M, Fossé A, Le Maréchal P, Olioso G, Yésou P (2012) Notes d'ornithologie française. Première mise à jour du nouvel inventaire des oiseaux de France. Ornithos 19:2-41

Estrada M (1996) Primary production in the northwestern Mediterranean. Sci Mar 60:55-64

Février Y, Plestan M, Thébault L, Hémery F, Denjau A, Sturbois A (2011) Stationnement du puffin des Baléares Puffinus mauretanicus en Côtes-d'Armor en 2010. Le Fou 83:39-48

Furness RW, Wade H (2012) Vulnerability of Scottish seabirds to offshore wind turbines. MacArthur Green, Glasgow

Furness RW, Wade HM, Masden EA (2013) Assessing vulnerability of marine bird populations to offshore wind farms. J Environ Manage 119:56-66

Genner MJ, Halliday NC, Simpson SD, Southward AJ, Hawkins SJ, Sims DW (2010) Temperature-driven phenological changes within a marine larval fish assemblage. J Plankton Res 32:699-708

Guilford TC, Meade J, Freeman R, Biro D and others (2008) GPS tracking of the foraging movements of Manx shearwaters Puffinus puffinus breeding on Skomer Island, Wales. Ibis 150:462-473 
Guilford T, Meade J, Willis J, Phillips RA and others (2009) Migration and stopover in a small pelagic seabird, the Manx shearwater Puffinus puffinus: insights from machine learning. Proc R Soc Lond B Biol Sci 276:1215-1223

Guilford T, Wynn RB, McMinn M, Rodriguez A and others (2012) Geolocators reveal migration and pre-breeding behaviour of the critically endangered Balearic shearwater Puffinus mauretanicus. PLoS ONE 7:e33753

Harrell FE (2012) rms: regression modeling strategies. R package version 3.5-0

ICES (2008a) Report of the working group on anchovy (WGANC). Report No. ICES CM 2008 ACOM:04, ICES, Copenhagen

ICES (2008b) Report of the Working Group on Seabird Ecology (WGSE). ICES, Lisbon

Irigoien X, Fernandes JA, Grosjean P, Denis K, Albaina A, Santos M (2009) Spring zooplankton distribution in the Bay of Biscay from 1998 to 2006 in relation with anchovy recruitment. J Plankton Res 31:1-17

Laneri K, Louzao M, Martinez-Abrain A, Arcos JM and others (2010) Trawling regime influences longline seabird bycatch in the Mediterranean: new insights from a smallscale fishery. Mar Ecol Prog Ser 420:241-252

Le Mao P, Yésou P (1993) The annual cycle of Balearic shearwaters and West-Mediterranean yellow legged gulls: some ecological considerations. In: Aguilar JS, Monbailliu X, Paterson AM (eds) Status and conservation of seabirds. Proc 2nd Mediterranean Seabird Symp. SEO/Birdlife, Madrid, p 135-145

Lewison R, Oro D, Godley B, Underhill L and others (2012) Research priorities for seabirds: improving conservation and management in the 21st century. Endang Species Res 17:93-121

Liéron V (2000) Le puffin des Baléares (Puffinus mauretanicus) dans les Côtes-d'Armor. Le Fou 52:14-19

Louzao M, Hyrenbach KD, Arcos JM, Abello P, Gil de Sola L, Oro D (2006) Oceanographic habitat of an Endangered Mediterranean procellariiform: implications for marine protected areas. Ecol Appl 16:1683-1695

Louzao M, Delord K, Garcia D, Boue A, Weimerskirch H (2012) Protecting persistant dynamic oceanographic features: transboundary conservation efforts are needed for the Critically Endangered Balearic shearwater. PLoS ONE 7:e35728

> Luczak C, Beaugrand G, Jaffre M, Lenoir S (2011) Climate change impact on Balearic shearwater through a trophic cascade. Biol Lett 7:702-705

Mayol-Serra J, Aguilar JS, Yésou P (2000) The Balearic shearwater Puffinus mauretanicus: status and threats. In: Yesou P, Sultana J (eds) Monitoring and conservation of birds, mammals and sea turtles of the Mediterranean and Black Seas. Environmental Protection Department, Malta, p 24-37

Oppel S, Meirinho A, Ramirez I, Gardner B, O'Connell AF, Miller PI, Louzao M (2012) Comparison of five modelling techniques to predict the spatial distribution and abundance of seabirds. Biol Conserv 156:94-104

> Oro D, Aguilar JS, Igual JM, Louzao M (2004) Modelling demography and extinction risk in the endangered Balearic shearwater. Biol Conserv 116:93-102

> Péron C, Grémillet D (2013) Tracking through life stages: adult, immature and juvenile autumn migration in a long-lived seabird. PLoS ONE 8:e72713

Péron C, Grémillet D, Prudor A, Pettex E and others (2013) Importance of coastal Marine Protected Areas for the conservation of pelagic seabirds: The case of Vulnerable yelkouan shearwaters in the Mediterranean Sea. Biol Conserv 168:210-221

Phillips RA, Silk JRD, Croxall JP, Afanasyev V (2006) Yearround distribution of white-chinned petrels from South Georgia: relationships with oceanography and fisheries. Biol Conserv 129:336-347

Pianalto S, Buanic M, de Kergariou E, Thébault L, Yésou P (2013) Nouvel hivernage massif du puffin des Baléares Puffinus mauretanicus en Bretagne (hiver 2012-2013). Ornithos 20:206-209

Pinheiro J, Bates D, DebRoy S, Sarkar D, R Core Development Team (2012) nlme: linear and nonlinear mixed effects models. R package version 3.1-103

Plestan M, Ponsero A, Yésou P (2009) Forte abondance du puffin des Baléares Puffinus mauretanicus en Bretagne (hiver 2007-2008). Ornithos 16:209-213

Poot M (2005) Large numbers of Balearic shearwater Puffinus mauretanicus along the Lisbon coast. Airo 15:43-50

Poulard JC, Blanchard F (2005) The impact of climate change on the fish community structure of the eastern continental shelf of the Bay of Biscay. ICES J Mar Sci 62: 1436-1443

R Development Core Team (2011) R: A language and environment for statistical computing. R Foundation for Statistical Computing, Vienna

Richardson J, Wood AG, Neil A, Nowacek D, Moore M (2012) Changes in distribution, relative abundance, and species composition of large whales around South Georgia from opportunistic sightings: 1992 to 2011. Endang Species Res 19:149-156

Ruiz A, Marti R (2004) La Pardela de Balear. SEO, Birdlife, Conselleria de Medi Ambient del Govern de les Illes Balears, Madrid

Shaffer SA, Tremblay Y, Weimerskirch H, Scott D and others (2006) Migratory shearwaters integrate oceanic resources across the Pacific Ocean in an endless summer. Proc Natl Acad Sci USA 103:12799-12802

Tasker ML, Hope Jones P, Dixon T, Blake BF (1984) Counting seabirds at sea from ships: a review of methods employed and a suggestion for a standardized approach. Auk 101:567-577

Tétard A, Boon M, Bennett D, Berthou P and others (1995) Catalogue international des activités des flottilles de Manche, approche des interactions techniques (International catalogue of fishing fleet activity in the English Channel, in relation to technical interactions. IFREMER, Brest

Thébault L (2011) A propos de deux cas de capture accidentelle de puffins des Baléares Puffinus mauretanicus en baie de Lannion par des pêcheurs plaisanciers. Le Fou 84:31-34

Thébault L, de Kergariou E, Uguen R, Provost JY (2010) Effectifs sans précédent de puffins des Baléares Puffinus mauretanicus en baie de Lannion (juillet-août 2010). Le Fou 83:39-48

Thébault L, Yésou P, Brereton T (2012) Le puffin des Baléares Puffinus mauretanicus en Bretagne en 2010. Le Fou 86:27-40

Troost G (2012) Trektellen. www.trektellen.nl/ (accessed 1 Oct 2013)

Varty N, Tanner K (2009) Background document for Balearic shearwater Puffinus mauretanicus. Report No. 413/2009, OSPAR Commission, London

Votier SC, Bearhop S, Attrill MJ, Oro D (2008a) Is climate 
change the most likely driver of range expansion for a critically endangered top predator in northeast Atlantic waters. Biol Lett 4:204-205

Votier SC, Birkhead TR, Oro D, Trinder M and others (2008b) Recruitment and survival of immature seabirds in relation to oil spills and climate variability. J Anim Ecol 77:974-983

Vous KS (1976) The birds of the tropical 'middle seas', past and present. In: Acta XVI Congressus Internationalis. Ornithologici, Canberra, p 697-704

Webb A, Durinck J (1992) Counting birds from ship. Manual for aeroplane and ship surveys of waterfowl and seabirds. IWRB Spec Publ 19:24-37

WindPower (2012) Wind turbines and wind farms database. www.thewindpower.net/country-datasheet-windfarms1 -france.php (6/7/2012)

Witt MJ, Hardy T, Johnson L, McClellan CM and others (2012) Basking sharks in the northeast Atlantic: spatiotemporal trends from sightings in UK waters. Mar Ecol Prog Ser 459:121-134

Wynn RB (2009) Balearic shearwaters in UK and Irish waters from 2004 to 2006. Br Birds 102:320-354

Wynn RB, Brereton T (2008) SeaWatch SW Annual Report 2007. National Oceanography Centre, Southampton

Editorial responsibility: Rebecca Lewison, San Diego, California, USA
Wynn RB, Brereton T (2009) SeaWatch SW Annual Report 2008. National Oceanography Centre, Southampton

Wynn RB, Yésou P (2007) The changing status of Balearic shearwater in northwest European waters. Br Birds 100: 392-405

Wynn RB, Josey SA, Martin AP, Johns DG, Yésou P (2007) Climate-driven range expansion of a critically endangered top predator in northeast Atlantic waters. Biol Lett 3:529-532

Wynn RB, Brereton T, Jones A, Lewis KM (2010a) SeaWatch SW Annual Report 2009. National Oceanography Centre, Southampton

Wynn RB, McMinn M, Rodriguez A (2010b) The predation of Balearic shearwaters by peregrine falcons. Br Birds 103: 350-356

Yésou P (1991) Puffin des Anglais Puffinus puffinus. In: Yeatman Berthelot D (ed) Atlas des oiseaux de France en hiver. Société Ornithologique, Paris, p 58-59

Yésou P (2003) Recent changes in the summer distribution of the Balearic shearwater Puffinus mauretanicus off western France. Sci Mar 67:143-148

Yésou P, Thébault L, Pfaff E (2011) Le puffin des Baléares Puffinus mauretanicus en Bretagne en 2009. Ar Vran 22: 2-19

Submitted: October 21, 2013; Accepted: May 14, 2014

Proofs received from author(s): July 10, 2014 